\title{
10 powodów, dla których warto wybierać preparat złożony zawierający perindopril, indapamid i amlodipinę w jednej tabletce
}

\author{
10 reason why you should choose a fixed-dose combination containing \\ perindopril, indapamide and amlodipine in a single pill
}

Filip M. Szymański

I Katedra i Klinika Kardiologii Warszawskiego Uniwersytetu Medycznego

\section{Streszczenie}

Preparaty złożone stanowią przyszłość leczenia hipotensyjnego. Lekarze mają coraz więcej doświadczeń praktycznych w ich stosowaniu, a także są świadkami wdrażania nowych, złożonych preparatów pojawiających się na rynku farmaceutycznym, które polepszają współpracę z chorym, ułatwią leczenie i stopniowo zwiększają odsetek osób z prawidłowo kontrolowanym ciśnieniem tętniczym w Polsce. Na rynku coraz częściej pojawiają się już nie tylko preparaty dwuskładnikowe, ale także zawierające trzy leki. Wybór spośród wielu dostępnych preparatów często bywa kłopotliwy. Zadaniem poniższego artykułu jest odpowiedzieć na pytanie, dlaczego warto stosować preparat wieloskładnikowy zawierający perindopril, indapamid i amlodipinę. Przedstawionych 10 argumentów z pewnością nie wyczerpuje wszystkich zalet stosowania takiego preparatu, jednak stanowią wskazówkę, dlaczego taki lek to obecnie jedno z najnowocześniejszych, najskuteczniejszych i najlepiej tolerowanych potrójnych zestawień dostępnych na polskim rynku farmaceutycznym, które nie tylko jest korzystne dla pacjentów, ale - być może - niedługo odmieni oblicze farmakoterapii.

Słowa kluczowe: preparat złożony, polypill, perindopril, indapamid, amlodipina

(Folia Cardiologica 2015; 10, 2: 106-113)

\section{Wstęp}

Nadciśnienie tętnicze jest jednym z najszerzej rozpowszechnionych czynników ryzyka chorób układu sercowo-naczyniowego na świecie, który w bezpośredni sposób odpowiada za znaczną liczbę zgonów. Skuteczne leczenie nadciśnienia tętniczego ciągle jeszcze pozostaje dużym wyzwaniem ze względu na charakter choroby i przewlekły proces jej leczenia. Jednym z rozwiązań, które potencjalnie mogą ułatwić leczenie, zarówno poprzez większą skuteczność osiągania docelowych wartości ciśnienia tętniczego, jak i ułatwienie przestrzegania zaleceń terapeutycznych, są preparaty złożone (FDC, fixed-dose combinations) - zarówno dwuskładniowe, jak i nowocześniejsze zawierające trzy leki hipotensyjne. W obliczu wielu dostępnych na rynku preparatów często problemem pozostaje wybranie zestawienia optymalnego, zawierającego najlepsze leki. Celem niniejszego artykułu jest udowodnienie, że na rynku polskim już jest „prawie idealny” złożony preparatem hipotensyjny. Ukazuje to przedstawionych poniżej 10 odpowiedzi na pytanie: Dlaczego warto stosować preparat wieloskładnikowy zawierający perindopril, indapamid i amlodipinę?

... ponieważ to pierwszy prawdziwy polypill/ /polycap na polskim rynku

Idealny polypill/polycap (od ang. poly - 'wiele', pill - 'tabletka', cap - 'kapsułka’) od dawna jest niejako Świętym

Adres do korespondencji: dr n. med. Filip M. Szymański, I Katedra i Klinika Kardiologii, Warszawski Uniwersytet Medyczny, ul. Banacha 1a, 02-097 Warszawa, tel.: 482259919 58, faks: 2259919 57, e-mail: filip.szymanski@wum.edu.pl 
Graalem farmakologii. Idea stosowania takiego leku byłaby prosta - powinien on w jednej tabletce zawierać wszystkie substancje, jakie mogą być wskazane do stosowania u pacjenta z chorobą układu sercowo-naczyniowego. Według hipotezy zaproponowanej przez Walda i Lawa [1] zastosowanie preparatu zawierającego kwas acetylosalicylowy, kwas foliowy, statynę oraz trzy leki hipotensyjne o działaniu plejotropowym (w małych dawkach) miałoby obniżyć ryzyko choroby niedokrwiennej serca o 88\%, a udaru mózgu o 80\% [1]. Tego typu lek miałby być odpowiedni dla niemalże wszystkich pacjentów i przyjmowany tylko raz dziennie miałby albo leczyć choroby układu sercowo-naczyniowego, albo zapobiegać ich wystąpieniu. Dziś oczywiście wiadomo, że takie panaceum nie istnieje. Niemniej jednak z idei polypill/polycap narodziło się kilka badań oraz nowych rodzajów preparatów leczniczych, które zmieniły oblicze farmakoterapii.

Pierwsze zakrojone na szeroką skalę badanie dotyczące preparatu określanego nazwą Polycap ${ }^{\circledR} 0$ akronimie TIPS (The Indian Polycap Study) przeprowadzono w Indiach wśród pacjentów w wieku 45-80 lat, bez rozpoznanej choroby układu sercowo-naczyniowego, ale obciążonych jednym czynnikiem ryzyka ich wystąpienia [2]. Zastosowany w nim preparat zawierał 5 leków: kwas acetylosalicylowy (100 mg), simwastatynę (20 mg), atenolol (50 mg), ramipril (5 mg) oraz diuretyk tiazydowy (12,5 mg). W badaniu wykazano, że Polycap ${ }^{\circledR}$ obniżał wartości ciśnienia tętniczego i częstości rytmu serca oraz wykładników funkcji płytek krwi porównywalnie, jak pojedyncze zastosowane w nim substancje. Nieco mniej istotna była redukcja stężenia cholesterolu frakcji LDL (low-density lipoprotein). Preparat był natomiast bardzo dobrze tolerowany. Czy w dzisiejszych czasach jest pożądane stosowanie właśnie takiego polypill/polycap? Odpowiedź, oczywiście, brzmi „nie”. Po pierwsze kwas acetylosalicylowy nie jest obecnie wskazany u każdego pacjenta w prewencji pierwotnej, po drugie jego dawka, być może, była zbyt duża i powinna zostać ograniczona do $75 \mathrm{mg} /$ dobe. Po trzecie, zastosowana simwastatyna obecnie nie jest najbardziej optymalną z dostępnych statyn, co - być może - skłaniałoby do zastosowania innego leku z grupy statyn lub innej dawki statyny. Po czwarte, również zaproponowane beta-adrenolityk oraz diuretyk tiazydowy nie są obecnie ani lekami nowoczesnymi, ani optymalnymi u wszystkich pacjentów. Powinno się też preferować inhibitory konwertazy angiotensyny o jak najdłuższym czasie działania.

U progu 2015 roku, myśląc o idealnej polypill/polycap, skupilibyśmy się raczej, po pierwsze, na preparacie nieprzeznaczonym dla wszystkich, ale opracowanym do potrzeb leczenia szerokiej grupy pacjentów z jednym schorzeniem. Po drugie, musiałby to być preparat zawierający jedne z najlepszych dostępnych obecnie molekuł, które by się uzupełniały i wzajemnie znosiły swoje działania niepożądane. Na rynku polskim już taki jest - to preparat złożony przeznaczony do leczenia nadciśnienia tętniczego, a zawierający perindopril, indapamid oraz amlodipinę. Ma on wszystkie zalety pierwszych polypill/polycap i jest pozbawiony ich wad, o czym jest mowa w dalszych częściach tego artykułu.

\section{... ponieważ stosowanie preparatów wieloskładnikowych usankcjonowano w europejskich wytycznych ESC/ESH oraz wytycznych PTNT}

Obecnie preparaty wieloskładnikowe nie są już tylko przyszłością. Preparaty złożone - początkowo zawierające dwa leki, a później także nowocześniejsze, trójlekowe kombinacje - od jakiegoś czasu odgrywają w leczeniu nadciśnienia tętniczego rolę na tyle znaczącą, że włączono je w schematy terapeutyczne i usankcjonowano zarówno w wytycznych opracowanych przez Europejskie Towarzystwo Kardiologiczne (ESC, European Society of Cardiology) i Europejskie Towarzystwo Nadciśnienia Tętniczego (ESH, European Society of Hypertension), jak i w wytycznych Polskiego Towarzystwa Nadciśnienia Tętniczego (PTNT) [3, 4]. W wytycznych europejskich podano, że skojarzenie substancji hipotensyjnych w preparacie złożonym może być rekomendowane i preferowane w celu redukcji liczby przyjmowanych leków, co sprzyja poprawie przestrzegania zaleceń terapeutycznych. Co więcej, w tych wytycznych wspomniano także o użyteczności preparatów typu polypill, zwracając jednak uwagę, że muszą one zawierać dobrze przebadane substancje [3]. W wytycznych PTNT napisano natomiast: „W leczeniu skojarzonym w celu zwiększenia skuteczności leczenia warto wykorzystywać preparaty złożone (...). Stosowanie preparatów złożonych w mniejszych dawkach zwiększa skuteczność hipotensyjną preparatu złożonego, a jednocześnie mniejsze dawki minimalizują ryzyko wystąpienia zdarzeń niepożądanych, zależnych od wielkości dawki tych leków. Preparaty złożone są zalecane zamiast monoterapii u pacjentów z nadciśnieniem tętniczym drugiego stopnia i/lub chorobami współistniejącymi, kiedy korzystne jest jednoczesne działanie obu składowych" [4]. W Polsce istnieje także jeszcze jeden dokument ukierunkowany na problematykę leczenia preparatami złożonymi, którym jest stanowisko PTNT i ekspertów Sekcji Farmakoterapii Sercowo-Naczyniowej Polskiego Towarzystwa Kardiologicznego [5]. Wspomniany dokument zamyka stwierdzenie, że uzasadnione jest, aby „(...) na co dzień korzystać z przypomnianych powyżej połączeń lekowych, uzyskiwać coraz więcej doświadczeń praktycznych w ich stosowaniu, a także być przygotowanym na wdrożenie nowych, złożonych preparatów pojawiających się na rynku farmaceutycznym, które polepszą współpracę z chorym, ułatwią leczenie i zwiększą, w co wierzymy, 
odsetek osób z prawidłowo kontrolowanym ciśnieniem tętniczym w Polsce w przyszłości" [5].

\section{... ponieważ zawiera perindopril}

Perindopril, indapamid i amlodipina zawarte w omawianym preparacie złożonym to substancje dobrze przebadane i szeroko stosowane. Każda z tych molekuł charakteryzuje się długim czasem działania. Większość lekarzy jest świadoma ich skuteczności klinicznej i dobrze zna badania, w których potwierdzono znaczenie tych trzech substancji w farmakoterapii nadciśnienia tętniczego. W tym miejscu należy jedynie wspomnieć o wynikach kilku z najważniejszych badań dotyczących tych leków.

W odniesieniu do perindoprilu jednym z takich badań było na przykład badanie EUROPA (EURopean trial On reduction of cardiac events with Perindopril in stable coronary Artery disease), które nie dotyczyło wprawdzie pacjentów z nadciśnieniem tętniczym, ale obejmowało osoby ze stabilną chorobą wieńcową [6]. Niemniej jednak w badaniu tym wykazano nie tylko skuteczne obniżenie ciśnienia tętniczego ze średniego 137/82 do 128/78 mm Hg, ale także dowiedziono, że stosowanie perindoprilu łączyło się z 20-procentową redukcją ryzyka zgonu z przyczyn sercowo-naczyniowych, zawału serca lub zatrzymania krążenia. Pokazało to, że perindopril jest substancją nie tylko skuteczną hipotensyjnie, ale wykazującą również dodatkowe korzystne właściwości u pacjentów ze stabilną chorobą wieńcową.

\section{... ponieważ zawiera indapamid}

Skuteczność i bezpieczeństwo indapamidu w połączeniu z wymienionym wyżej perindoprilem przebadano na przykład w badaniu ADVANCE (Action In Diabetes and Vascular Disease: Preterax and Diamicron Controlled Evaluation), w którym oceniano skuteczność hipotensyjną tych dwóch leków oraz ich wpływ na powikłania mikro- i makronaczyniowe u chorych na cukrzycę typu 2 [7]. Dowiedziono, że takie połączenie powoduje nie tylko istotne obniżenie wartości skurczowego i rozkurczowego ciśnienia tętniczego, ale - co istotniejsze - jego stosowanie łączy się z redukcją liczby incydentów sercowo-naczyniowych, a także ryzyka zgonu. Ostatnio opublikowane wyniki badania ADVANCE-ON, w którym obserwowano pacjentów przez kolejne 5 lat, potwierdziły istotne zmniejszenie śmiertelności całkowitej i z przyczyn sercowo-naczyniowych u chorych leczonych połączeniem perindoprilu z indapamidem [8]. Także w badaniu HYVET (The Hypertension in the Very Elderly Trial), w którym indapamid i/lub perindopril stosowano u pacjentów podeszłym w wieku, wykazano skuteczność, korzyści i bezpieczeństwo związane z zastosowaniem tego diuretyku [9].

Indapamid jest także substancją, która ma przewagę nad innym stosowanym obecnie diuretykiem tizydowym
- hydrochloriotiazydem. Ze względu na korzystniejszy profil metaboliczny oraz więcej dowodów na korzyści w zakresie prewencji ryzyka sercowo-naczyniowego w dużych badaniach klinicznych indapamid powinien być obecnie preferowanym przedstawicielem tej grupy zamiast takiego leku, jak hydrochlorotiazyd, co podkreślono między innymi w wytycznych PTNT [4].

\section{... ponieważ zawiera amlodipinę}

Amlodipina to nie tylko jeden z najczęściej stosowanych antagonistów wapnia, ale także jeden z leków, które najczęściej stanowią drugi składnik preparatów złożonych. Wynika to z faktu, że amlodipina wykazuje niewiele interakcji, można ją bezpiecznie stosować z lekami z takich grup, jak inhibitory konwertazy angiotensyny, diuretyki, sartany i beta-adrenolityki. Jest to lek nie tylko bezpieczny, ale także skuteczny. Spośród badań, w których stwierdzono jego skuteczność, można wymienić na przykład ASCOT, CAMELOT i ACCOMPLISH. Wykazano w nich, że połączenie amlodipiny z inhibitorem konwertazy angiotensyny lub diuretykiem łączy się ze skutecznością hipotensyjną oraz z redukcją liczby niekorzystnych incydentów sercowo-naczyniowych w grupie pacjentów z chorobą wieńcową lub obciążonych wysokim ryzykiem sercowo-naczyniowym oraz ze spowolnieniem progresji miażdżycy tętnic wieńcowych [10-12].

\section{... ponieważ połączenie tych trzech leków uzupełnia się farmakologicznie}

Perindopril, indapamid i amlodipina należą do różnych grup leków hipotensyjnych, co sprawia, że ich mechanizm działania zależy od różnych procesów, co z jednej strony pozwala na większą skuteczność, a z drugiej - obniża ryzyko działań niepożądanych. Perindopril, poprzez hamowanie produkcji angiotensyny II, będzie powodował rozkurcz mięśni gładkich tętniczek, zmniejszał opór obwodowy oraz zwiększał pojemność minutową serca. Indapamid spowoduje zwiększenie diurezy i zmniejszenie objętości krwi krążącej, a także zmniejszy opór obwodowy, a amlodipina zapewni rozszerzenie łożyska naczyniowego ze zmniejszeniem oporu obwodowego i obciążenia następczego mięśnia sercowego, a także jego zapotrzebowania na tlen. Ponadto, co ważne szczególnie w początkowym okresie leczenia, przed uzyskaniem stężenia stacjonarnego, maksymalne stężenie osiągane w osoczu, a więc maksymalne działanie hipotensyjne, w przypadku tych trzech leków występuje w różnym czasie. Indapamid osiąga je po około godzinie, perindopril - po 3-6 godzinach, natomiast amlodipina - po 6-12 godzinach. Łączne zastosowanie perindoprilu, indapamidu oraz amlodipiny zapewnia zatem skuteczne, długotrwałe działanie hipotensyjne dzięki połączeniu mechanizmów, między innymi zmniejszenia objętości krwi krążącej, wazorelaksacji oraz wazodylatacji [13-15], przy niskim ryzyku hipotonii. Co najważniejsze jednak, wszystkie te mechanizmy przekładają 


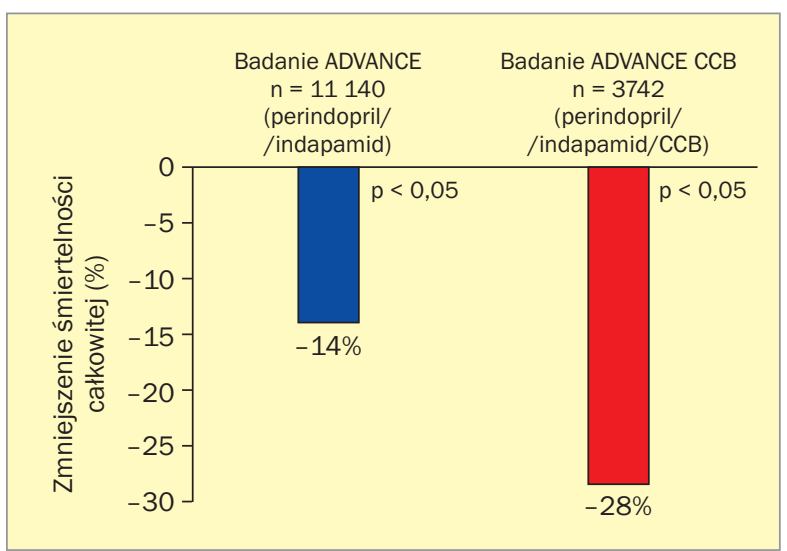

Rycina 1. Wpływ połączenia perindoprilu, indapamidu i amlodipiny na śmiertelność całkowitą; CCB (calcium channel blocker) - antagonista wapnia

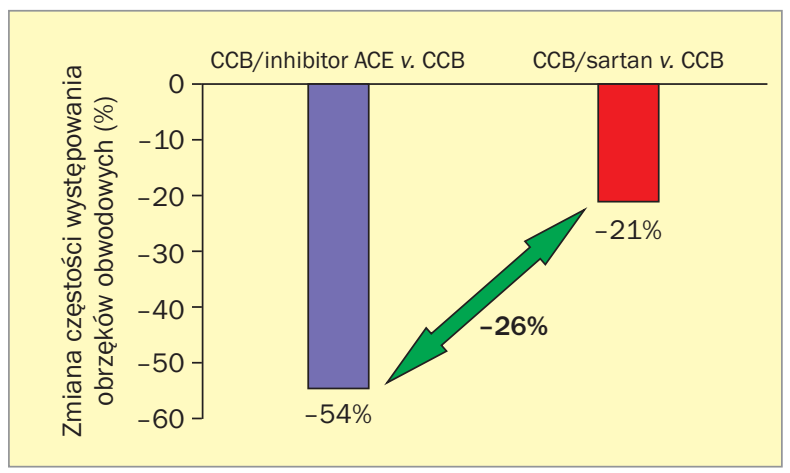

Rycina 2. Redukcja częstości występowania obrzęków związana z łącznym stosowaniem antagonisty wapnia (CCB, calcium channel blocker) i inhibitora konwertazy angiotensyny (ACE, angiotensin-converting enzyme)

się na istotną, długotrwałą redukcję śmiertelności całkowitej; śmiertelność jest najmniejsza w przypadku stosowania tych trzech leków łącznie (ryc. 1) [16].

W kontekście działań niepożądanych prezentowanego połączenia leków najwyższym potencjalnym ryzykiem ich wystąpienia cechuje się amlodipina. Najczęstsze związane z nią działanie niepożądane, nierzadko prowadzące do przerwania leczenia, to występowanie obrzęków podudzi. Jednak wyniki badań wskazują, że łączne stosowanie antagonisty wapnia z inhibitorem konwertazy angiotensyny pozwala zmniejszyć częstość występowania obrzęków podudzi aż o ponad połowę i jest to redukcja istotnie większa niż możliwa to osiągnięcia za pomocą sartanu (ryc. 2) [17]. Jednocześnie kaszel wywołany inhibitorami konwertazy angiotensyny jest istotnie ograniczany przez antagonistów wapnia. W przypadku łącznego stosowania obu leków kaszel ulega istotnemu zmniejszeniu u 61\% pacjentów [18]. Sprawia to, że omawiane leki doskonale się uzupełniają, tworząc optymalny preparat hipotensyjny.

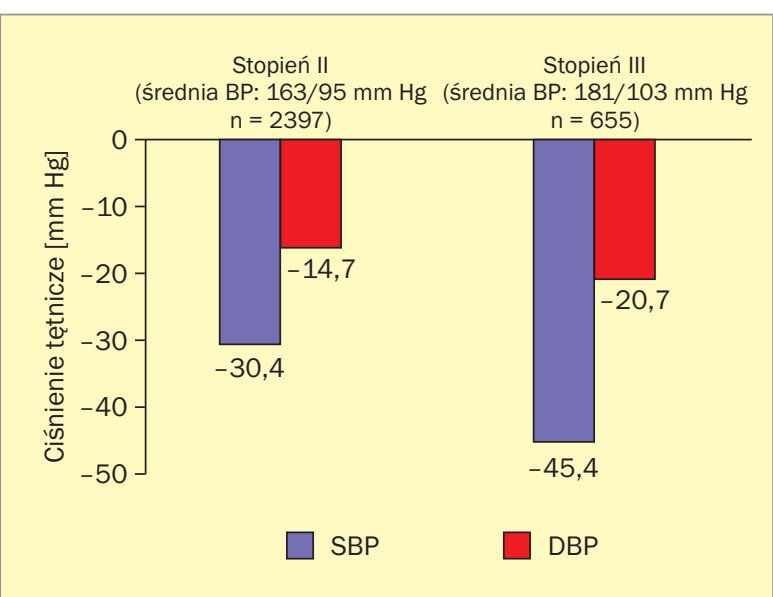

Rycina 3. Skuteczność hipotensyjna związana ze stosowaniem perindoprilu, indapamidu i amlodipiny; *dla wszystkich zmian $\mathrm{p}<0,0001$; BP (blood pressure) - ciśnienie tętnicze; SBP (systolic blood pressure) - skurczowe ciśnienie tętnicze; DBP (diastolic blood pressure) - rozkurczowe ciśnienie tętnicze

\section{... ponieważ to jedna z niewielu (jedyna?) trójka, w odniesieniu do której istnieją konkretne dowody z zakresu EBM}

Obecnie dane dotyczące skuteczności większości preparatów złożonych są efektem ekstrapolacji dużych badań dotyczących substancji składowych. Oczywiście nie jest to zgodne z założeniami medycyny opartej na dowodach naukowych (EBM, evidence-based medicine). W przypadku większość trójskładnikowych preparatów złożonych próżno szukać rzetelnych badań opartych na zasadach EBM. Wyjątek stanowi połączenie perindoprilu, indapamidu i amlodipiny. Poświęconym ocenie jego skuteczności badaniem PIANIST (Perindopril-Indapamide plus AmlodipiNe in high rISk hyperTensive patients) objęto 4731 pacjentów z grup wysokiego lub bardzo wysokiego ryzyka sercowo-naczyniowego ze źle kontrolowanym nadciśnieniem tętniczym, u których zastosowano te trzy leki [19]. W ciągu trwającego 4 miesiące leczenia zaobserwowano, że łączne stosowanie tych trzech leków powoduje obniżenie ciśnienia tętniczego o 30,4/14,7 mm Hg u chorych z nadciśnieniem 2. stopnia i o 45,4/20,7 mm Hg u chorych z nadciśnieniem 3. stopnia (ryc. 3). Skuteczność hipotensyjną wykazano również w grupach chorych, którzy wcześniej byli poddani terapii skojarzonej, na przykład inhibitor konwertazy angiotensyny + amlodipina czy antagonista receptora $\mathrm{AT}_{1}$ dla angiotensyny II + hydrochlorotiazyd. Łącznie osiągnęło $72 \%$ badanych optymalną kontrolę ciśnienia tętniczego.

W badaniu PIANIST wykazano jeszcze jedną bardzo ważną cechę takiego połączenia. Perindopril, indapamid oraz amlodipina zastosowane łącznie nie tylko wykazywały wysoką skuteczność hipotensyjną, ale w sposób korzystny wpływały także na profil metaboliczny pacjentów (tab. 1). 
Tabela 1. Zmiany w profilu metabolicznym związane z jednoczesnym stosowaniem perindoprilu, indapamidu i amlodipiny (na podstawie [19])

$\begin{array}{lcccc}\text { Parametr } & \text { Wyjściowo (średnia) } & \text { Po 4 miesiącach (średnia) } & \text { Zmiana (\%) } & p \\ \text { Cholesterol całkowity [mmol/l] } & 5,6 & 5,0 & -9,5 & <0,0001 \\ \text { Triglicerydy [mmol/l] } & 2,1 & 1,8 & -11,5 & <0,0001 \\ \text { Glukoza [mmol/l] } & 6,3 & 6,0 & -4,9 & <0,0001 \\ \mathrm{HbA}_{1 \mathrm{c}}(\%) & 7,2 & 7,2 & -0,3 & <0,0001 \\ \text { Kwas moczowy [umol/l] } & 323,0 & 311,6 & -3,5 & <0,0001 \\ \text { Kreatynina [mmol/l] } & 90,9 & 88,8 & -2,3 & <0,0001 \\ \text { Potas [mmol/l] } & 4,4 & 4,4 & -0,5 & 0,004 \\ \text { Sód [mmol/l] } & 139,5 & 139,4 & -0,1 & 0,4\end{array}$

$\mathrm{HbA}_{1 c}$ - hemoglobina glikowana

Zastosowane leki istotnie obniżały stężenia między innymi cholesterolu całkowitego, triglicerydów, glukozy oraz kwasu moczowego, co poza działaniem hipotensyjnym leku może się przełożyć na dodatkową redukcję ryzyka sercowo-naczyniowego.

W opublikowanej w minionym roku subanalizie z badania ADVANCE, tj. badaniu ADVANCE CCB, zaobserwowano zmniejszenie śmiertelności całkowitej o 28\% wśród 3427 chorych przyjmujących perindopril z indapamidem i antagonistą wapnia. Redukcja ta nie zależała od wysokości ciśnienia tętniczego [16].

\section{... ponieważ istnieje bardzo szerokie spektrum pacjentów z nadciśnieniem tętniczym, dla których ten lek przeznaczono}

Powyższy argument ma niejako podwójne dno. Z jednej strony, z badania NATPOL 2011 wynika, że nadciśnienie tętnicze dotyka około 32\% dorosłych Polaków. Bardzo duża część z nich do osiągnięcia prawidłowej kontroli wartości ciśnienia tętniczego wymaga stosowania wielu substancji. Można przypuszczać, że wielu nadal otrzymuje zbyt mało leków, bo przecież kontrola hipotensyjna w naszym kraju wciąż nie jest optymalna (ryc. 4).

Co więcej, nadciśnienie tętnicze rzadko jest chorobą „izolowaną". Znaczna część pacjentów, zwłaszcza starszych, choruje jednocześnie na inne choroby układu sercowo-naczyniowego takie jak choroba niedokrwienna serca, czy niewydolność serca. Substancje wchodzące w skład omawianego preparatu wieloskładnikowego, czyli perindopril, indapamid i amlodipina, w wytycznych PTNT zalecano jako leki pierwszego lub drugiego wyboru u pacjentów z nadciśnieniem tętniczym i szeregiem chorób współistniejących [4].

Inhibitory konwertazy angiotensyny, a więc także perindopril, to leki „z wyboru” między innymi u pacjentów z chorobą niedokrwienną serca i po incydentach sercowo-naczyniowych, z niewydolnością serca, niektórymi powikłaniami narządowymi nadciśnienia tętniczego czy z zaburze-

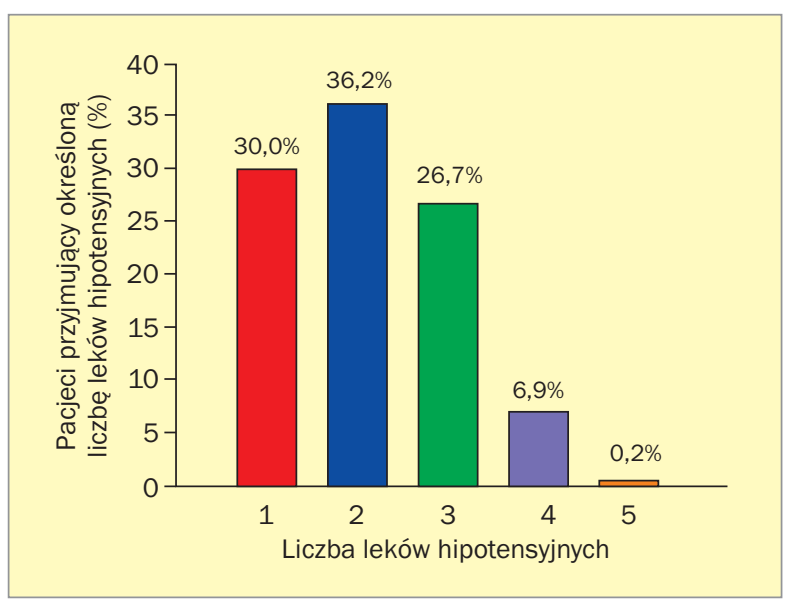

Rycina 4. Ilość substancji hipotensyjnych stosowanych przez pacjentów z nadciśnieniem tętniczym, na podstawie badania NATPOL 2011

niami metabolicznymi. Diuretyki, a zwłaszcza indapamid, są preferowane w leczeniu nadciśnienia tętniczego u osób w podeszłym wieku, po przebytym udarze mózgu oraz z cukrzycą i niewydolnością serca. Natomiast dihydropirydynowi antagoniści wapnia, czyli na przykład amlodipina, to leki preferowane u osób w podeszłym wieku, z astmą lub przewlekłą obtruacyjną chorobą płuc, a także z chorobą niedokrwienną serca, zaburzeniami metabolicznymi czy białkomoczem (tab. 2) [4].

Na podstawie powyższej listy można łatwo wywnioskować, że preparat złożony, który zawiera wszystkie trzy leki - perindopril, indapamid oraz amlodipinę będzie lekiem bardzo uniwersalnym, odpowiednim dla bardzo wielu (prawie wszystkich?) pacjentów z nadciśnieniem tętniczym trafiających do gabinetu kardiologa. Warto w tym miejscu odpowiedzieć sobie na pytanie: kiedy ostatnio leczyłem/ /leczyłam pacjenta z nadciśnieniem tętniczym, który nie miałby wskazania do stosowania chociaż jednej z wymienionych grup leków? 
Tabela 2. Grupy pacjentów z nadciśnieniem tętniczym, u których wskazane jest stosowanie antagonistów konwertazy angiotensyny, diuretyków oraz dihydropirydynowych antagonistów wapnia (zmodyfikowano na podstawie [4])

\begin{tabular}{|c|c|c|c|}
\hline Stan kliniczny & $\begin{array}{l}\text { Diuretyk, np. } \\
\text { INDAPAMID }\end{array}$ & $\begin{array}{c}\text { Dihydropirydynowy } \\
\text { antagonista wapnia, np. } \\
\text { AMLODIPINA }\end{array}$ & $\begin{array}{l}\text { Inhibitor konwertazy } \\
\text { angiotensyny, np. } \\
\text { PERINDOPRIL }\end{array}$ \\
\hline Przerost lewej komory serca & & & I \\
\hline Przebyty zawał serca & & & I \\
\hline Niewydolność serca & ॥ & & I \\
\hline Choroba niedokrwienna serca & & II & I \\
\hline \multicolumn{4}{|l|}{ Migotanie przedsionków } \\
\hline Przebyty udar mózgu & I & & II \\
\hline Zespół metaboliczny & & II & I \\
\hline Cukrzyca & ॥ & II & I \\
\hline \multicolumn{4}{|l|}{ Dna moczanowa } \\
\hline Nadciśnienie tętnicze u osób w podeszłym wieku & 1 & 1 & II \\
\hline Izolowane nadciśnienie skurczowe & I & I & ॥ \\
\hline Albuminuria/białkomocz & & $\|$ & I \\
\hline Przewlekła choroba nerek & & & I \\
\hline Niewydolność nerek & & & I \\
\hline Zaburzenia potencji & & & I \\
\hline Astma oskrzelowa/COPD & & I & \\
\hline
\end{tabular}

Wspomniane „drugie dno" to argumenty przemawiające za stosowaniem perindoprilu, indapamidu i amlodipiny w postaci jednej tabletki leżące po stronie lekarza. Lecząc powszechnie występujące schorzenie, jakim niewątpliwe jest nadciśnienie tętnicze, wielu lekarzy lubi mieć „jeden dobry lek" odpowiedni dla wielu przypadków tej samej choroby. Bardzo łatwo się przyzwyczaić do rutynowego stosowania preparatu wieloskładnikowego, który jest skuteczny hipotensyjnie, wykazuje korzyści kliniczne u dużej grupy pacjentów oraz zapewnia dobrą tolerancję leczenia i profil bezpieczeństwa. Jakże wygodne i proste dla lekarza jest tego typu leczenie... Poza tym jest jeszcze prozaiczny powód, ale jakże istotny (np. w specyfice praktyki ambulatoryjnej) czy nie jest łatwiej wypisać na recepcie jeden preparat wieloskładnikowy niż trzy różne leki?

\section{... ponieważ preparat „potrójny” cechują jeszcze wyższe compliance, adherence, persistence}

Jednymi z wykładników skuteczności leczenia, istotnym zwłaszcza w przypadku chorób przewlekłych, takich jak nadciśnienie tętnicze, jest długotrwałe stosowanie się przez pacjentów do zaleconych form terapii. Lecząc pacjenta z chorobą przewlekłą, lekarze praktycy muszą skoncentrować się na kilku aspektach. Poza prawidłową diagnozą oraz zaleceniem prawidłowego leczenia ważne jest, czy pacjent regularnie przyjmuje zalecone leki, a w odległym aspekcie również to, czy jest w stanie się stosować do zaleconego leczenia przez długi czas, często wiele lat. Opisane parametry są określane przez trzy anglojęzyczne zwroty, które do tej pory nie znalazły godnych odpowiedników w języku polskim:

- compliance (ang. 'stosowanie się', 'podporządkowanie się');

- adherence (ang. 'przestrzeganie zaleceń');

- persistence (ang. 'wytrwałość').

Pierwsze dwa zwroty odnoszą się do podobnego problemu, ale różnią się w jednym, zasadniczym aspekcie. Compliance rozumie się jako stopień, w jakim zachowanie pacjenta odpowiada zaleceniom lekarza i nie uwzględnia ono wpływu chorego na wybór schematu leczenia, natomiast adherence to stopień, w jakim zachowania pacjenta odpowiadają zaleceniom uzgodnionym z lekarzem i odnosi się do sytuacji, w której pacjent jest partnerem w procesie leczenia. Już samo zadanie pytania „Czy woli Pan/Pani przyjmować te same leki w postaci kilku tabletek czy jeden tabletki preparatu złożonego?" zamienia compliance w adherence, a pacjentowi w pewnym stopniu daje poczucie bycia partnerem lekarza. Natomiast persistence określa, czy leczony pacjent przestrzega schematu leczenia w perspektywie długoterminowej. 
Jedynie długotrwałe, regularne przyjmowanie leków pozwala, po pierwsze, na skuteczną redukcję wartości ciśnienia tętniczego i, po drugie, obniża ryzyko sercowo-naczyniowe. W metaanalizach u pacjentów z chorobami układu sercowo-naczyniowego wykazano, że zastosowanie preparatu złożonego poprawia adherence o 1/3 oraz ponad 2-krotnie zwiększa szanse na dobrą persistence [20, 21]. Wynika to z faktu, że zastosowanie preparatu złożonego zmniejsza liczbę przyjmowanych tabletek, upraszcza schemat leczenia i poprawia osiąganie docelowych wartości ciśnienia tętniczego [22]. Większość z badań wchodzących w skład cytowanych metaanaliz dotyczyła porównania stosowania preparatu zawierającego dwie substancje i pojedynczych tabletek. Zdrowy rozsądek oraz pewne pojedyncze przesłanki dostępne w piśmiennictwie pozawalają sądzić, że w przypadku preparatów „potrójnych” efekt ten będzie jeszcze większy, ale na poświęcone temu zagadnieniu badania pozostaje jeszcze poczekać [23]. Jeżeli pacjentowi łatwiej jest przyjmować jedną tabletkę niż dwie, to czy nie będzie jeszcze łatwiej przyjmować jedną tabletke zamiast trzech?

W przypadku politerapii pacjenci często przyjmują leki według schematu „rano i wieczorem”, zwykle w celu uniknięcia potencjalnych interakcji, a w przypadku leków hipotensyjnych - w celu zapewnienia trwałego efektu hipotensyjnego. Jednak w większości przypadków, o ile nie wykazano tego w całodobowych pomiarach ciśnienia tętniczego, nie ma przesłanek do tego, aby leki hipotensyjne, zwłaszcza te długodziałające, stosować według schematu „rano i wieczorem”.

\section{... ponieważ preparaty wieloskładnikowe są przyszłością leczenia hipotensyjnego}

Na początku 2015 roku trzeba mieć świadomość, że mimo gwałtownego rozwoju medycyny wprowadzanie do receptariusza nowych molekuł wcale nie jest tak częste, jak mogłoby się to wydawać. W roku 2014 Agencja ds. Żywności i Leków (FDA, Food and Drug Administration) zarejestrowała jedynie 41 nowych molekuł. Również w ostatnich latach liczby te utrzymywały się na podobnym poziomie. Z tego jedynie 10 substancji znajdzie zastosowanie w leczeniu szeroko rozumianych chorób układu sercowo-naczyniowego oraz jego czynników ryzyka (włączając w to między innymi leczenie cukrzycy czy zaburzeń dobowego rytmu snu i czuwania). W sposób bezpośredni na układ sercowo-naczyniowy będą działać w zasadzie jedynie dwie nowe molekuły - worapaksar oraz droksydopa - przeznaczone odpowiednio do redukcji ryzyka zawału serca i udaru mózgu u pacjentów z grupy wysokiego ryzyka oraz do leczenia neurogennej hipotensji ortostatycznej [24].
W 2014 roku, podobnie jak w wielu poprzednich latach, nie zarejestrowano żadnego nowego leku stosowanego w leczeniu nadciśnienia tętniczego. W ostatnim czasie nie opublikowano również żadnych badań II czy III fazy wskazujących, aby ta sytuacja miała w najbliższym czasie ulec zmianie.

Nie można mieć jednak poczucia, że z tego powodu pacjenci są leczenia „starymi” lekami. Obecne w tej chwili na rynku farmaceutycznym molekuły pod względem „stażu” to już wyłącznie leki o udowodnionej skuteczności i bezpieczeństwie przez lata potwierdzonych nie tylko w badaniach klinicznych, ale także w badaniach obserwacyjnym z udziałem „prawdziwych” populacji pacjentów.

Jaka jest zatem przyszłość leczenia hipotensyjnego? Zgodnie z tytułem niniejszego fragmentu są to właśnie preparaty złożone. Celami postępu farmakoterapii nadciśnienia tętniczego są dziś poprawa komfortu leczenia, przestrzeganie zaleceń, ustalenie bardziej optymalnych schematów leczenia i ograniczenie działań niepożądanych za pomocą już dostępnych substancji. Między innymi cytowane wyżej badania kliniczne wskazują, że cele te osiąga się za pomocą preparatów złożonych.

Świadomi faktu, że w armamentarium leków coraz częściej będą się pojawiać nowe preparaty złożone, lekarze praktycy muszą się nauczyć z jednej strony chętniej sięgać po tego typu leki, a z drugiej wybierać zestawienia najbardziej wartościowe, takie jak na przykład perindopril, indapamid i amlodipina.

\section{Podsumowanie}

Powyższych 10 argumentów z pewnością nie wyczerpuje wszystkich zalet stosowania preparatów złożonych, zwłaszcza zawierającego perindopril, indapamid i amlodipinę - obecnie jednego z najnowocześniejszych, najskuteczniejszych i najlepiej tolerowanych potrójnych zestawień dostępnych na polskim rynku farmaceutycznym. Łatwość i wszechstronność leczenia takim preparatem sprawia, że coraz większa grupa lekarzy chętnie sięga po preparaty złożone, w tym zawierające trzy leki hipotensyjne, dzięki czemu zyskują one coraz większy udział w rynku farmaceutycznym.

\section{Konflikt interesów}

Autor deklaruje brak konfliktu interesów.

\section{Podziękowania}

Pomysł artykułu był inspirowany wykładem prof. dr. hab. n. med. Krzysztofa J. Filipiaka, FESC. 


\section{Abstract}

Fixed-dose combinations (FDC) are the future of antihypertensive treatment. Doctors gain more experience in their practical application, as well as witness the introduction of new, complex formulas appearing on the pharmaceutical market that improve patients' adherence and gradually increase the proportion of subjects with well-controlled blood pressure in Poland. A large number of FDCs appears on the market containing not only two-component formulations, but also those with 3 drugs. Choosing from the many formulations is often hard. This article is intended to answer the question: Why should we use an FDC containing perindopril, indapamide and amlodipine? 10 presented arguments certainly do not exhaust all the advantages of using such a product - but are an indication of why the drug is at the moment one of the most modern, most effective and best tolerated triple combinations available on the Polish pharmaceutical market. Such combination is not only beneficial for patients, but be may soon change the face of pharmacotherapy.

Key words: fixed-dose combination, polypill, perindopril, indapamide, amlodipine

(Folia Cardiologica 2015; 10, 2: 106-113)

\section{Piśmiennictwo}

1. Wald N.J., Law M.R. A strategy to reduce cardiovascular disease by more than 80\%. BMJ 2003; 326: 1419.

2. Indian Polycap Study (TIPS); Yusuf S., Pais P., Afzal R. i wsp. Effects of a polypill (Polycap) on risk factors in middle-aged individuals without cardiovascular disease (TIPS): a phase II, double-blind, randomised trial. Lancet 2009; 373: 1341-1351.

3. Mancia G., Fagard R., Narkiewicz K. i wsp. 2013 ESH/ESC guidelines for the management of arterial hypertension: the Task Force for the Management of Arterial Hypertension of the European Society of Hypertension (ESH) and of the European Society of Cardiology (ESC). Eur. Heart J. 2013; 34: 2159-2219.

4. Widecka K., Grodzicki T., Narkiewicz K. i wsp. Zasady postępowania w nadciśnieniu tętniczym - 2011 rok. Wytyczne Polskiego Towarzystwa Nadciśnienia Tętniczego. Nadciśn. Tętn. 2011; 15: 55-82.

5. Wożakowska-Kapłon B., Filipiak K.J., Czarnecka D. i wsp. Miejsce leków złożonych w terapii nadciśnienia tętniczego - aktualne problemy w Polsce Stanowisko Ekspertów Polskiego Towarzystwa Nadciśnienia Tętniczego i Sekcji Farmakoterapii Sercowo-Naczyniowej Polskiego Towarzystwa Kardiologicznego. Kardiol. Pol. 2013; 71: 433-438.

6. Fox K.M.; EURopean trial On reduction of cardiac events with Perindopril in stable coronary Artery disease Investigators. Efficacy of perindopril in reduction of cardiovascular events among patients with stable coronary artery disease: randomised, double-blind, placebo-controlled, multicentre trial (the EUROPA study). Lancet 2003; 362: 782-788.

7. Patel A.; ADVANCE Collaborative Group; MacMahon S., Chalmers J., Neal B. i wsp. Effects of a fixed combination of perindopril and indapamide on macrovascular and microvascular outcomes in patients with type 2 diabetes mellitus (the ADVANCE trial): a randomised controlled trial. Lancet 2007; 370: 829-840.

8. Zoungas S1., Chalmers J., Neal B. i wsp.; ADVANCE-ON Collaborative Group. Follow-up of blood-pressure lowering and glucose control in type 2 diabetes. N. Engl. J. Med. 2014 Oct 9; 371: 1392-1406. doi: 10.1056/NEJMoa1407963.

9. Beckett N.S., Peters R., Fletcher A.E. i wsp.; HYVET Study Group. Treatment of hypertension in patients 80 years of age or older. N. Engl. J. Med. 2008; 358: 1887-1898.

10. Dahlöf B., Sever. P.S., Poulter N.R. i wsp.; ASCOT Investigators. Prevention of cardiovascular events with an antihypertensive regimen of amlodipine adding perindopril as required versus atenolol adding bendroflumethiazide as required, in the Anglo-Scandinavian Cardiac Outcomes Trial-Blood Pressure Lowering Arm (ASCOT-BPLA): a multicentre randomised controlled trial. Lancet 2005; 366: 895-906.

11. Nissen S.E., Tuzcu E.M., Libby P. i wsp.; CAMELOT Investigators. Effect of antihypertensive agents on cardiovascular events in patients with coronary disease and normal blood pressure: the CAMELOT study: a randomized controlled trial. JAMA 2004; 292: 2217-2225.

12. Jamerson K., Weber M.A., Bakris G.L. i wsp.; ACCOMPLISH Trial Investigators. Benazepril plus amlodipine or hydrochlorothiazide for hypertension in high-risk patients. N. Engl. J. Med. 2008; 359: 2417-2428.

13. Epstein B.J., Vogel K., Palmer B.F. Dihydropyridine calcium channel antagonists in the management of hypertension. Drugs 2007; 67: 1309-1327.

14. Robinson D.M., Wellington K. Indapamide sustained release: a review of its use in the treatment of hypertension. Drugs 2006; 66: 257-271.

15. Hurst M., Jarvis B. Perindopril: an updated review of its use in hypertension. Drugs 2001; 61: 867-896.

16. Chalmers J., Arima H., Woodward M. i wsp. Effects of combination of perindopril, indapamide, and calcium channel blockers in patients with type 2 diabetes mellitus: results from the Action In Diabetes and Vascular Disease: Preterax and Diamicron Controlled Evaluation (ADVANCE) trial. Hypertension 2014; 63: 259-264.

17. Makani H., Bangalore S., Romero J. i wsp. Effect of renin-angiotensin system blockade on calcium channel blocker-associated peripheral edema. Am. J. Med. 2011; 124: 128-135.

18. Fogari R., Zoppi A., Mugellini A. i wsp. Effects of amlodipine, nifedipine GITS, and indomethacin on angiotensin-converting enzyme inhibitor-induced cough: a randomized, placebocontrolled, double-masked, crossover study. Curr. Ther. Res. Clin. Exp. 1999; 60: 121-124.

19. Kalman Toth on behalf of PIANIST Investigators. Antihypertensive Efficacy of Triple Combination Perindopril/Indapamide Plus Amlodipine in High-Risk Hypertensives: Results of the PIANIST Study (Perindopril-Indapamide plus AmlodipiNe in high rISk hyperTensive patients). Am. J. Cardiovasc. Drugs 2014; 14: 137-145.

20. Sherrill B., Halpern M., Khan S. i wsp. Single-pill vs free-equivalent combination therapies for hypertension: a meta-analysis of health care costs and adherence. J. Clin. Hypertens. (Greenwich) 2011; 13 : 898-909.

21. de Cates A.N., Farr M.R., Wright N. i wsp. Fixed-dose combination therapy for the prevention of cardiovascular disease. Cochrane Database Syst. Rev. 2014; 4: CD009868.

22. Bangalore S, Ley L. Improving treatment adherence to antihypertensive therapy: the role of single-pill combinations. Expert Opin. Pharmacother. 2012; 13: 345-355.

23. Taylor A.A., Ragbir S. Three in one: safety, efficacy, and patient acceptability of triple fixed-dose combination medicine in the management of hypertension. Patient Prefer. Adherence 2012; 6: 555-563.

24. http://www.fda.gov/Drugs/DevelopmentApprovalProcess/DrugInnovation/default.htm. Dostęp on-line 31.12.2014 r. 